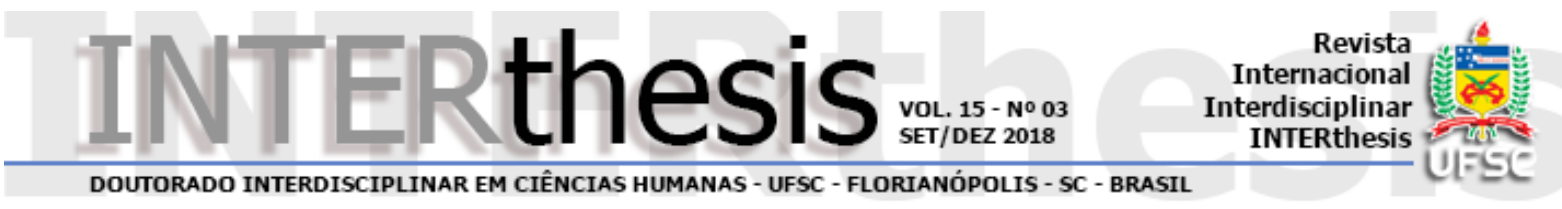

\title{
BIO-ECONOMY AT THE CROSSROADS OF SUSTAINABLE DEVELOPMENT
}

\author{
José Guadalupe Vargas-Hernandez ${ }^{1}$ \\ Karina Pallagst ${ }^{2}$ \\ Patricia Hammer ${ }^{3}$
}

\section{Abstract:}

This study aims to review, analyze and systematize the knowledge created on bioeconomy to develop a conceptual and theoretical framework based on the transdisciplinary study of biology and socioeconomy to be used in further research. It begins from the questioning of what are the benefits that bio-economy has compared to the neoclassical economy. The methods employed are the critical analytic, descriptive, deductive-inductive and suggests a holistic and transdisciplinary approaches. As a result, the core of the study presents the principles under which this new scientific paradigm in sustainable development can continue creating more scientific knowledge to be used in the formulation and implementation of strategic choices for the bio production, bio distribution and bio consumption process.

Keywords: Bio-Economy. Green Economy. Knowledge-Based Economy. Sustainable Development. Strategic Choices.

\section{INTRODUCTION}

Any nation of the World faces major environmental, economic and social challenges to be addressed to change for sustainable development and the better the way to live and work. Bio-economy is a 'greener' alternative that have impacts on natural and environmental resources, food, soil, land and livelihoods. Bio-economy has a relevant impact in important bio products such as textiles, cosmetics, bioenergy, biofuels, building products, and other byproducts and bio power. Bioeconomy serves a market of environmentally sustainable satisfactors, products and services and to keep in pace in the long term to become global, it requires more

\footnotetext{
1 Research professor of University Center for economic and Managerial Sciences, University of Guadalajara, México E-mail: jvargas2006@gmail.com

2 Research professor of International Planning Systems Faculty of Spatial and Environmental Planning, Technische Universität Kaiserslautern, Germany E-mail: karina.pallagst@ru.uni-kl.de

${ }^{3}$ Research assistant of International Planning Systems Faculty of Spatial and Environmental Planning, Technische Universität Kaiserslautern, Germany E-mail: patricia.hammer@ru.uni-kl.de
} 
research and development. Bio-economy is globally influencing biotechnological research and development, business models and market structure.

Bio-economics is considered as a more advanced scientific development than economics because it relies on the evolutionary process of humanity and nature. The advance of economic science extends to consider biological evolution, biology and thermodynamics as important foundations of the economic process. The bioeconomy connects and expands economics and biology to anchor in its empirical prediction to give it the power of regeneration and sustainability to the activities of the socioeconomic and biological systems.

This study analyzes the recent developments on bio-economy. It reviews the conceptualization of bio-economy, green economy and ecological economics to analyze the deficiencies of classic economy leading to present the bio-economics as the new epistemological paradigm inextricable linked to sustainable development. From this framework, there are derived at the core of the subject and object of study some principles offered as the basis for further research: Circular economy, sustainable development, holistic and transdisciplinary approaches, innovation culture and capacity creation, knowledge-based economy, global ethics, social capital and culture of peace.

Finally, the study considers the importance of formulation and implementation of the bio-economy as a strategy to enable and ensure results in terms of contributions for the sustainable development of renewable resources. Also some concluding remarks are offered.

\section{CONCEPTUALIZATION OF BIO-ECONOMY}

The concept of bio-economy is relatively new to name those economic activities derived from the biosciences advances and surge in the scientific knowledge in biotechnology, genetics, genomics, etc., to achieve practical applications from biological processes. The term bio-economics was coined by Georgescu-Roegen to explain the biological origin of the economic process and thus spotlight the problem of mankind's existence with a limited store of accessible resources, unevenly located and unequally appropriated (Georgescu-Roegen 1977: 361 ). Bio-economy is the sustainable production and conversion of biomass into a range of goods and services, among others food, health, fiber and industrial products 
and energy. The term 'bio-economic' is used to indicate both economic and biophysical components (Knowler 2002).

Bio-economy is a concept related to the economic activities derived from utilizing natural and biological resources or bioprocesses to produce bio products. Bio-economy is an aggregated set of economic operations and activities related with biological products to capture economic value, growth and welfare benefits for human development. The concept of a bio-economy refers to that economy where the basic components of materials, chemicals and energy come from renewable biological resources, such as plant and animal sources. This type of economy can meet many of the requirements for sustainability from environmental and social aspects as it is designed and implemented intelligently.

Returning to the definition of the concept of bio-economics, the OECD suggests that it can be understood as -the aggregate set of economic operations in a society that uses the latent value of biological products and processes to capture new benefits of growth and well-being for citizens and nations. This first definition, from the year 2006, essentially includes the same idea with regard to the means to achieve growth and prosperity, as is clear from the description of the OECD from 2009 (OECD 2009).

Turning to a European vision, the EC defines the bio-economy in its policy package as the production of renewable biological resources and the conversion of these resources and waste streams into value-added products such as food, feed, bio-based products and bioenergy (European Commission, 2015). The bio-economy encompasses agriculture, forestry, fisheries, food and biotechnology, as well as a wide range of industrial sectors, ranging from energy and chemical production to construction and transportation.

The concept of bio-economics has several meanings: It is the efficient management of human resources (Clark, 2010) and is considered as an analogy of biology to explain economic theory. The concept of bio-economics as the biological analysis of economic relations, which as dynamic systems can be effected, for example, through frames of reference, mental schemes and instruments of thought analysis.

The concept of bio-economy is under debate (Levidow, Birch, Papaioannou 2012). A bio-economy can be defined as an economy in which the basic building blocks for materials, chemicals and energy are derived from renewable biological 
resources (McCormick \& Kautto, 2013). Bio-economy is defined as the global industrial transition of sustainably utilizing renewable aquatic and terrestrial biomass resources in energy, intermediate, and final products for economic, environmental, social, and national security benefits (USDA 2015). The bio-economy is defined as an economy based on the sustainable production and conversion of renewable biomass into a range of bio-based products, chemicals, and energy (de Besi and McCormick, 2017).

Awareness on the concept of the bio-economy as potential in biosciences and biotechnology.

While the concept of bio-economics began initially from the science of biotechnology, then it has expanded to incorporate other ideas. Biotechnology can be understood as the science of using living things to produce goods and services. Therefore, it involves manipulating and modifying organisms to create new and practical applications for primary production, health and industry.

Another meaning of the concept is the one that considers the bio-economy as the influence that has the satisfaction of the human needs like the biological conditions in the economic behavior.

\subsection{BIO-ECONOMY AS GREEN ECONOMY}

Bio-economy also called green economy can be defined as one that has low carbon emissions, uses resources efficiently and is socially inclusive (PNUMA, 2016). The bio-economy sector is a warrantor for a green economy.

The 'bio-economy' agenda has developed the concept 'green economy' that emerged at the 2012 Rio+20 summit and is promoted by the United Nations Environment Programme to pursue natural renewable resources bioenergy and sustainable biological products (Socaciu, 2014). The agenda for bio-economy has been pushed by large corporations and developed states linked to green economy and the Knowledge-Based Bio-Economy (Hall, and Zacune, 2012). The Rio+20 agenda 'Towards a Green Economy' gave rise to the bio-economic strategy for sustainable development and economic growth (European Commission 2012). The European Union promotes among its Member States the commitment to the agenda of "Green economy", bioenergy (Paul, 2013) and agro fuels as an alternative to fossil fuels (Hall and Zacune 2012, OECD, 2009). 
Bio-economics biologicalises the natural environment and the biological resources of business activities as intrinsic and inextricable elements of mutualistic coevolution. The bio-economy integrates the green economy that seeks to respond to the challenges of food security and clean bioenergy.

\subsection{BIO-ECONOMY AS ECOLOGICAL ECONOMICS}

However, bio-economics is also called ecological economics. For some authors the bio-economy is the ecological economy that reconciles the economy and the ecology, that at the same time that looks for the economic efficiency, takes care of the natural resources that are essential for the humanity. The bio-economic approach calls for a change in values on the use of available resources and energy to be conserved for the use if future generations. The bio-economy is the basis of the business of ecological projects, agricultural, etc. Bio-economics studies the biological origin of economic process and the human activities associated with a limited stock of available and accessible resources that are unevenly located and unequally appropriated (Mayumi, 2001).

Ecological disasters in recent years as a result of the subordination of the laws of nature to the laws of the market economy and that has demonstrated the destructive capacity of the forces of nature, to the point that has created an awareness by the environmental care. Some analysts consider that the bio-economy approach is destructive and should be restructured from an agro ecological perspective.

\section{THE DEFICIENCIES OF NEOCLASSICAL ECONOMICS}

The economy as a science oriented by the competition has serious methodological deficiencies that the bio-economy tries to overcome through bio centric processes and of bio-economic balance centered in the cooperation for the sustainable development and the conservation of the nature and the environment in their interactions with the humanity. From a holistic perspective, the interactions between biological and socioeconomic systems result in the field of bio-economics. The interactions of the natural biological and economic processes that give rise to the 
bio-economy have an impact on the complex and uncertain phenomena of the biosphere.

The Physiocrats subordinated reproduction and economic transformation to nature, classical economics to capital, later to the goal of market equilibrium and the financial system with economic neoliberalism. The heterodox economy is more oriented to the human aspect with approaches such as humanist socialism that resists the clashes of the liberal economy and analyze the contradictions of economic liberalism with the argument that the labor force is not a commodity that separates from the human being.

The market economy reduces natural, social and moral values but cannot regulate the behavior of nature. The First Report of the Club of Rome (Club de Roma, 1972) which warns about the limits of economic growth and the Brundtland Report (Brundtland Gro Harlem, 1987) that reports threats to the mechanisms that regulate nature, emerges the issues for sustainable development to maintain the balance between the interdependence of the economy, nature and the biosphere.

\section{BIO-ECONOMY: A NEW ECONOMIC EPISTEMOLOGY PARADIGM}

Bio-economics as a discipline is a new paradigm in environmental economic development (Soedigdo et al. 2014). The emergence of Bio-economics as a different science to economics and biology represents a new paradigm in scientific disciplinary evolution for the study and analysis of the bio-economic causes of the environmental impacts of human actions (Mohammadian 2000). The interactions of biological and economic systems are integrated in the bio-economy from a new perspective that represents a paradigm shift. As an interdisciplinary science, bio-economics synthesizes sciences based on the empiricism of biology and the humanism of economics, resulting in a new, more holistic paradigm because it attempts to explain the interactivity of biological systems and nature with economics and the social.

Bio-economics represents a paradigmatic change in the evolution of disciplines whose main task is to investigate the problems that arise from the impact of human enterprise on the environment. These problems are not only due to purely biological causes, or to purely economic causes. Bio-economics has been the result and in turn is provoking paradigmatic change in the epistemology of research for the generation of innovative theoretical and empirical knowledge with applications that 
are highly significant for their contributions. The paradigm focused on bio-economic development is based on the holistic perspective that results from the interaction of biological, socioeconomic and environmental development to explain the coevolution of human development that guarantees the provision of resources for present and future generations.

The bio-economic development paradigm (Mohammadian, 2000) is an alternative to prevent the accelerated depletion of natural biological resources, mitigate environmental degradation, reduce economic inequality and social inequity. The community participation and paradigm has been changing with the bio-economy process (Henry and Roche 2013). Sustainability preserves the identity and integrity of bio-economic systems by enhancing self-sufficiency and equity and respect for biospheric equilibria as the criteria for regulation of trade and economic activity in opposition to the neoclassical economic paradigm endorsing global trade to stimulate economic growth.

The new paradigm complements the tangible and intangible resources, the objective with the subjective and the feelings with the facts with a sustainable and sustained growth orientation, with a material and economic operational benefit. The new paradigm of production and market, which has been call cognitive capitalism and bio-economics, in a word, bio-capitalism (Fumagalli 2007). Bio-economics makes aware of the interactions of biological and socio-economic systems, to reach a conciliation, to adopt a holistic research. The three disciplines of the economyenvironment have offered a change of perspective, and a non-paradigm shift as bioeconomics does.

\section{BIO-ECONOMY AS A STRATEGY}

Bio-economy strategy aims on self-sufficiency in energy, raw materials and securing availability of biomass, low-carbon and resource-efficient society. A bioeconomy strategy is aimed to identify energy, environment, water, food, health, social, etc., challenges and act upon the critical bio-economy research from using waste materials to gain market value and growth. A bio-economy strategy links bioeconomy-based renewable resources with sustainability by ensuring sustainable production and use of biomass (Pfau, Hagens, Dankbaar, Smits 2014). 
The knowledge-based bio-economy is a sustainable economic strategy for the creation of sustainable natural capital (Birch, Levidow, and Papaioannou, 2010) that is oriented towards the formulation of sustainability policies, in a way that attempts to link bio-economics projects with the knowledge-based economy and technological innovation for the design of public policies and institutional practices (Franco, Goldfarb, Fig, Levidow, and Oreszczyn, 2011).

Bio-economics is presented as a win-win strategy. Bio-economy has been identified as a strategy and defined as encompassing the production of renewable biological resources and the conversion of these resources and waste streams into value added products, such as food, feed, bio-based products and bioenergy. Its sectors and industries have strong innovation potential due to their use of science, enabling and industrial technologies, along with local and tacit knowledge (European Commission, 2012, p. 3). The European Union's strategy adopted in 2012 and announced as innovation in the service of sustainable growth: a bio-economy for Europe promotes sustainable production and consumption capabilities based on life sciences to address the challenges of the environment, the use of energy and food security.

The bio-economy as a greening strategy is advancing amid the debates on the so-called green economy proposed by the United Nations Environment Program (PNUMA) to promote bio production. Bio-economy as strategy has solutions to environmental concerns and sustainable economic growth moving forward to renewable biological resources in an increasing market share (European Bioeconomy Panel and SCAR, 2014; European Commission, 2015). The European Union recommends the bio-economy to the Rio +20 agenda 'Towards a green economy' as a strategy to promote the sustainable development of environmental and natural resources efficiently, thereby making economic growth compatible and the sustainable use of biological and environmental resources (European Commission, 2015).

To target specific markets, sustainable bio-economy must study and analyze the development and functioning of the environment, development of sectors, identify global trends and challenges, opportunities and changes in drivers of marketing of products and services, the specific needs to satisfy. The study of the bio-economy raises the need for a behavioral change of production systems called to play a strategic role in providing a response to a set of global challenges, uses the system 
approach to analyze related fields such as green economics and energy efficiency and productivity processes taking into account climate variations and increasing restrictions on the quality of biodiversity and natural resources such as air, water and soil. This analysis is necessary to formulate and implement a strategy and policy actions. Strategy formulation formulate priorities for future bio-economy development.

A favorable operating environment, strategic choices and policy actions are drivers for business bio-economy development, growth and achieving competitiveness in a setting to operate. Strategic choices and implemented sustainable bio-economy policy actions to produce efficient goods and services targeted to satisfy the needs of consumers in the marketplace and aimed to support the growth of bio-economy business. Strategy choices implementation and policy actions supported by agents in the bio-economy sector to set up a program aimed for resource efficiency and low-carbon society.

The bio-economy as part of a comprehensive global strategy including the renewable energies is able to solve the problems of sustainable development (Piotrowski, Carus, Essel, 2015). A sustainable bio-economy strategy is aimed to generate bio-economy business growth from added value bio-economy products and services while securing the nature's ecosystems and providing sustainable global solutions for saving nature's diversity, global warming, air pollution, consumption standards, etc. Sustainable bio-economy strategy aims to economic growth generation from high added value products and services in the competitive bioeconomy business secured by natural ecosystems. Global bio-economy competitive strategy builds innovative firms supported by science and high technology research and structural conditions.

Productivity and performance of the bio-economy in sectors internationally competitive result in growing demand for innovative products, processes, and services.

Strategies for bio-economy development focus in priority areas related to research, development and innovation of new biotechnological and industrial bio products, relationships between firms, communities, research institutions and government to optimize the functioning of biomass use, funding the development of bio-based activities. Strategies on import of biomass as a raw material is required in some industries are related with the development certification process to ensure sustainability and not have negative economic, social and environmental impacts. 
Availability of biomass for the present and future of bio-economy is dependent on strategies on land use, agriculture, forest and the other natural and biological resources diversity. Also are important, technological development, economic and legal incentives (Welfe, Gilbert, Thornley, 2014).

Bio-economy strategies based on societal awareness and fostering research and innovation are aimed to the transition towards the development of a bio-based economy. To achieve a bio-economy transition, the development of some strategies and actions are required such as to invest in research and development, training human resources for innovative and completive skills and capabilities, to engage stakeholders in interactive processes of collaboration with bio-products to meet the market. A transition strategy towards a sustainable bio-economy has to face many factors with significant uncertainty, such as consumption patterns, climate change, sustainability risks, etc.

Some other important bio-economy strategies are designed more specifically to foster biotechnology, using biomass and waste residuals, promote collaboration relationships between different sectors and stakeholders, firms and research institutions, funding support, etc. A bio-economy research strategy should strengthen the interactions between the different stakeholders. Participation of stakeholders representing the bio-economy is vital to strategy formulation and implementation. The bio-economy research strategy is sustained by participation in research and development in collaborative projects between firms and science institutions aimed to achieve market leadership.

Research, development and innovation are the basis of the regional and industrial strategy for bio-economy development. Regional strategies for bioeconomy development are different and contextualized in its own strengths, capacities and capabilities (Paterman, 2014). Deployment of bio-economics specialization strategies can foster regional economic development and support regional bio-economy clusters. Research on bio-economy strategies at regional level is very limited and provide little knowledge on the bio-economy development.

Regional strategies can improve coordination and communication between groups and industry's platforms (BioPro Baden-Wuerttenberg, 2014), facilitates the role of local governments in supporting firms, research institutes to create bioeconomy partnerships and developing standards for public procurement and labels for bio-based products, recognized by consumers (Carrez, 2014). Regional 
collaboration between the different actors in the different regions have strategies for bio-economy development sustained by biotechnology, health and life sciences. Regional bio-economy strategies are supported by the provision of funding and subsidies for research, development, innovation, communication, diffusion and commercialization of bio-based activities and bio-products.

The development of a network system to support bio-economy business is relevant for the strategy implementation to enter a new international market in such areas as food, health, energy, etc. The global strategy of the bio-economy as an agenda of multinational corporations that are linked to local governments is based on processes of innovation and the sustainable development of the agricultural sector and the highly questioned natural resources. The corporate-led bio-economy agenda is a global strategy linking public and private sectors based on innovation and sustainable development. Strategic alliances for collaboration between public and private sectors are critical instruments for information sharing, the research and expansion of bio-economics, and to encourage new programs of bio production.

A knowledge-based strategy intends to foster skills particularly for innovative start-ups and SMEs. Companies across bio-economy sector should encourage professional participation to gain experience in the field through different strategies and actions such as lifelong learning.

The benefits of bio-economy have to be communicated to consumers who may sift consumption away from fossil-based products and towards sustainable bioproducts (FORMAS, 2012; TEM 2014). An external evaluation of the research bioeconomy strategy assesses the positive effects and the impact on groundwork progress for the development of a knowledge-based competitive bio-economy activities. The bio-economic model is an integrated approach for evaluation of fishery management strategies (Anderson and Seijo 2010; Armstrong and Sumaila 2000; Clark,1995).

A strategic plan on bio-economy is required to map future potential and directions, matching economic and social needs and formulating policy agendas. The strategist of the bio-economy should be to gradually integrate small-scale ecological practices as an alternative to the expanding biomass production (ETC Group, 2015) with increasing independence of fossil fuels. However, some analysts consider that the bio-economy agenda has limitations and suggests that strategies should include more elements of agro ecology. The bio-economy strategy becomes essential to the 
concept of circular economy in such activities as separation of bio-waste collection and use, process of biodegradation, sustainable bio production, etc. This bioeconomy strategy should be clear and transparent, engaging and involving all business, research and education institutions, community and social organizations and all levels of government institutions.

A sustainable bio-economic strategy requires an operating environment with access to sustainable biomass for the creation of new bio-economy business based on competence. Transition towards sustainable bio-economy needs strategies design and implementation for industrial biotechnological transformation from fossil fuels resources to biomass based production and the required consumer behavior changes (Birch, 2015).

These conditions can contribute to the creation of bio-economy business for sustainable development. Sustainable bio-economy development can be accelerated by systematic strategic choices and policy actions for achieving economic growth and well-being. Society structure must enable sustainable strategic choices and policy actions for bio-economy development targeted to offer alternative well-being services and products to consumer choices.

The bio-economy strategy should be more inclusive of ecological activities and techniques. The strategies of Bio-economy based on agro-industrial solutions needs to expand to include new forms of adding value and agricultural knowledge involving social and community innovation to biological resources (Birch and Tyfield, 2012; Schmidt et al, 2012; Levidow et al. 2012).

A research strategy should be based in a natural cycle of a bio based economy supported by a biological, ecology and technology systems in such a way that provide incentives to work and cooperate interdisciplinary. This strategy should develop the knowledge-based and innovation internationally competitive bioeconomy.

Active dialogue, participation and relationships of cooperation among citizens, firms, new social movements and governments are required to support bio-economic initiatives embraced by public policies. 


\section{CONCLUDING REMARKS}

The high dependence of today's economic development supported on fossilbased resources increases environmental sustainability concerns of production systems and food security. This situation justifies the urgent need for a transition from neoclassical economy type of development based on fossil resources towards a more sustainable development supported by the bio-economy based on biological resources and bio biological products. Sustainable development based on bioeconomy optimize the allocation of natural and biological renewable resources whilst increasing the environmental, food security, energy and health concerns.

The theoretical framework of bio-economics for sustainable development was created as an alternative to neoclassical economic development model. The economic development model based on neoclassical economics is being criticized for not addressing issues such as resource scarcity, environment, social institutions, social policy, social organization, entropy and bio-economics of economic activities.

The bio-economy sustainable development model focuses more on quality than on quantity as opposed to neoclassical economic development model. However, also the sustainable development model based on bio-economy is being under scrutiny. Some critical points addressed here regarding the sustainable development model are to consider natural resources as infinite goods which leads to an overexploitation, require massive inputs, and the production methods impact on agricultural land and the environment. This interpretation, which deals with similarities between economic and biological systems, has been harshly criticized. The explosive wave of bio-economics entails as policies the improvement in the quality of fuels and renewable energies, it is highly questioned and criticized for not delivering its promises.

This study has identified some principles of bio-economy which are critical issues affecting the prospects for the bio-economy based sustainable development. Therefore, the study concludes that bio-economy is at the crossroads of the sustainable development paradigm. 


\section{DESENVOLVIMENTO ECONÔMICO AMBIENTALMENTE SUSTENTÁVEL BASEADO EM BIOECONOMIA}

\section{Resumo:}

Este estudo tem como objetivo revisar, analisar e sistematizar o conhecimento criado sobre bioeconomia para desenvolver um arcabouço conceitual e teórico baseado no estudo transdisciplinar da biologia e da socioeconomia a ser utilizado em futuras pesquisas. Começa com o questionamento de quais são os benefícios que a bioeconomia possui comparada à economia neoclássica. Os métodos empregados foram o analítico crítico, descritivo, dedutivo-indutivo e sugere uma abordagem holística e transdisciplinar. Como resultado, o cerne do estudo apresenta os princípios sob os quais este novo paradigma científico em desenvolvimento sustentável pode continuar criando mais conhecimento científico a ser usado na formulação e implementação de escolhas estratégicas para o processo de bioprodução, bio-distribuição e bio-consumo.

Palavras-chave: Bio-Economia. Economia Verde. Economia baseada em Conhecimento. Desenvolvimento Sustentável. Escolhas Estratégicas.

\section{DESARROLLO ECONÓMICO AMBIENTALMENTE SOSTENIBLE BASADO EN LA BIOECONOMÍA}

\section{Resumen:}

Este estudio tiene como objetivo revisar, analizar y sistematizar el conocimiento creado sobre la bioeconomía para desarrollar un marco conceptual y teórico basado en el estudio transdisciplinario de la biología y la socioeconomía para ser utilizado en futuras investigaciones. Comienza desde el cuestionamiento de cuáles son los beneficios que la bioeconomía tiene en comparación con la economía neoclásica. Los métodos empleados son analíticos críticos, descriptivos, deductivos-inductivos y sugieren enfoques holísticos y transdisciplinarios. Como resultado, el núcleo del estudio presenta los principios bajo los cuales este nuevo paradigma científico en el desarrollo sostenible puede continuar creando más conocimiento científico para ser utilizado en la formulación e implementación de elecciones estratégicas para el proceso de bioproducción, biodistribución y bioconsumo.

Palabras clave: Bioeconomía. Economía Verde. Economía basada en el Conocimiento. Desarrollo Sostenible. Opciones Estratégicas. 


\section{REFERENCES}

ANDERSON, L. G. AND SEIJO, J. C. Bio-economics of Fisheries Management, JohnWiley and Sons, 2010.

ARMSTRONG, C.W. AND SUMAILA, U. R. Cannibalism and the optimal sharing of theNorth-EastAtlantic cod stock: a bio-economic model, Journal of Bio-economics, vol. 2, no. 2, pp. 99-115, 2000.

BIRCH, K. YORK UNIVERSITY. Toronto, ON, Canada. Phone interview and email correspondence. Personal communication, 7 January 2015.

BIRCH, K. LEVIDOW, L. Y PAPAIOANNOU, T. Sustainable Capital? The Neoliberalization of Nature and Knowledge in the European Knowledge-based Bioeconomy, Sustainability, 2, 2898-2918. 2010.

BIRCH, K.; TYFIELD, D. Theorizing the Bio-economy: Biovalue, Biocapital, Bioeconomics or What? Sci. Technol. Hum. Values 2012, 38, 299-327. 2012.

BIOPRO BADEN-WUERTTENBERG. Bio-economy: Baden-Württemberg Path towards a Sustainable Future. Available online:

http://www.biopro.de/biopro/downloads/index.html?lang=en

Acesso em 27 Mar 2014.

BRUNDTLAND GRO HARLEM. Our Common Future, Oxford University Press. 1987.

CARREZ, D. Clever Consult, Brussels, Belgium. Phone interview and email correspondance. PERSONAL COMMUNICATION, 9 April 2014.

CLARK C. W. Mathematical Bio-economics: The Mathematics of Conservation, 3rd Edition. Wiley. May 2010.

CLARK, C. W. MODELLING AND FISHERIES MANAGEMENT, John Wiley and Sons, 1995.

CLUB DE ROME. Halte à la croissance ?- traduction française Fayard. 1972. 
DE BESI, M. AND MCCORMICK, K. Towards a Bio-economy in Europe: National, Regional and Industrial Strategies. International Institute for Industrial Environmental Economics (IIIEE), Lund University. 2017.

ETC GROUP. The Bio-economy. http://etcgroup.org/issues/bio-economy 2015.

EUROPEAN COMMISSION. What is the Bio-economy. http://ec.europa.eu/ research/bio-economy/index.cfm. (2015).

EUROPEAN COMMISSION. Bio-economy Strategy. Available from: http://ec.europa.eu/research/bio-economy/policy/strategy en.htm. 2015.

EUROPEAN COMMISSION. Innovation for Sustainable Growth: A Bio-economy for Europe. Publication Office of the European Office: Luxembourg, 2012Available from: http://ec.europa.eu/research/ bio-economy/index.cfm?pg=policy\&lib=strategy 2012.

EUROPEAN BIO-ECONOMY PANEL AND SCAR. What Next for the European Bio-economy? Available from: http://ec.europa.eu/research/bio-economy/pdf/wherenext-for-european-bio-economy-report-0809102014 en.pdf. 2014.

FUMAGALLI, A. Bioeconomia e capitalismo cognitivo: Verso un nuovo paradigma di accumulazione. Roma: Carocci. 2007.

FORMAS. Swedish Research and Innovation Strategy for a Bio-Based Economy; The Swedish Research Council for Environment, Agricultural Sciences and Spatial Planning (FORMAS): Stockholm, Sweden, 2012.

FRANCO, J., GOLDFARB, L., FIG, D., LEVIDOW, L. Y ORESZCZYN, S.M. Agricultural Innovation: Sustaining What Agriculture? For What European BioEconomy? Project-wide final report. CREPE. 2011.

GEORGESCU-ROEGEN, N. Inequality, Limits and Growth from a Bio-economic Viewpoint, Review of Social Economy XXXV, 3: 361-375. 1977.

HALL, R. AND ZACUNE, J. Bio-economies: The EU's real 'Green Economy' agenda? World Development Movement and the Transnational Institute. 2012. 
HENRY M, ROCHE M. Valuing lively materialities: Bio-economic assembling in the making of new meat futures New Zealand. Geographer 69: 197-207. 2013.

KNOWLER, D. A. Review of selected bio-economic models with environmental influences in fisheries, J Bioecon, 4(2), 163-181, 2002.

LEVIDOW, L., K. BIRCH AND T. PAPAIOANNOU EU agri-innovation policy: Two contending visions of the bio-economy', Critical Policy Studies, 6(1), 40-65. 2012.

MAYUMI, K. The Origins of Ecological Economics. The bio-economics of Georgescu-Roegen Routledge Research in Environmental Economics. London and New York. Routledge. 2001.

MCCORMICK, K.; KAUTTO, N. The Bio-economy in Europe: An Overview. Sustainability 2013, 5, 2589-2608. 2013.

MOHAMMADIAN, M. Bio-economics: Biological Economics. Interdisciplinary Study of Biology, Economics and Education. Entrelíneas Editores. Madrid. 2000.

OECD The Bio-economy to 2030: Designing a Policy Agenda.

http://www.oecd.org/futures/bio-economy/2030. 2009.

PATERMANN, C. Member of the Bio-economy Council, Germany. Phone interview and email correspondence. Personal communication, 24 March 2014.

PFAU, S.; HAGENS, J.; DANKBAAR, B.; SMITS, A. Visions of Sustainability in Bioeconomy Research. Sustainability 2014, 6, 1222-1249. 2014.

PIOTROWSKI, S.; CARUS, M.; ESSEL, R. Global bio-economy in the conflict between biomass supply and demand. Nova Pap. 2015, 7, 1-14. 2015.

PNUMA. Programa de las Naciones Unidas para el Medio Ambiente. Hacia una economía verde: Guía para el desarrollo sostenible y la erradicación de la pobreza. 21 de noviembre de 2016, de Programa de las Naciones Unidas para el Medio Ambiente Sitio web: http://www.pnuma.org/eficienciarecursos/economia.php 2016.

SCHMIDT, O.; PADEL, S.; LEVIDOW, L. The bio-economy concept and knowledge base in a public goods and farmer perspective. Bio-Based Appl. Econ. 2012, 1, 4763. 2012. 
SOEDIGDO D, HARYSAKTI A, USOP TB. The elements driving local wisdom on the architecture Nusantara. J Perpect Archit 9 (1): 37-47. 2014.

SOCACIU, C. Bio-economy and green economy: European strategies, action plans and impact on life quality, Bulletin UASVM Food Science and Technology, 71(1). 2014.

USDA. An Economic Impact Analysis of the U.S. Biobased Products Industry A Report to the Congress of the United States of America, USDA 2015.

WELFE, A.; Gilbert, P.; THORNLEY, P. (2014). Increasing biomass resource availability through supply chain analysis. Biomass Bioenergy $2014,70,249-$ 266. 